\title{
No resuscitation for US technology office closed by Congress
}

Baltimore. Efforts to attract private finance to revive the former Office of Technology Assessment (OTA), which the Republicandominated Congress voted to close last September, have come to nothing, officials told the annual meeting of the American Association for the Advancement of Science in Baltimore, Maryland, last weekend.

Vary Coates, president of the Institute for Technology Assessment (ITA), which has been trying to pick up where the OTA left off, said that that philanthropic foundations did not want to give Congress the impression they were prepared to pay for work that Congress had chosen to jettison. The search for funds has "been a real disappointment", Coates said, as the foundations "are not in the institute-building business". Nor were they in a mood "to pick up functions that Congress is [cutting] off", for fear of encouraging further cuts.

The OTA, set up in 1973 to advise Congress on matters ranging from patenting of human genes to nuclear waste disposal, was shut down by Republican congressmen who challenged both the value and objectivity of its work, and wanted to be seen to be cutting Congress's own costs. It had 200 highly skilled staff and a $\$ 20$ million annual budget.

The ITA is now seeking grant support for individual technology assessment projects. It has no full-time staff, but has a small Washington office supported by a start-up grant from the Garfield Foundation, a trust connected to the Philadelphia-based publishers of The Scientist, a weekly newspaper.

Roger Herdman, the last director of the OTA, said that the organization's work was not being done by any other congressional agency. The only prospect for continuing it lay in "privatizing" it, he said. David Guston of Rutgers University, New Jersey, said that a "plausible opportunity" existed for the ITA to occupy a niche, selling technology assessment to the 51 state governments.

Todd La Porte, OTA vice president, reported that five European bodies set up in OTA's mould - in Denmark, France, Germany, the Netherlands and the United Kingdom - are "progressing nicely", although each body is coming to reflect the political system in its own country.

The weakness of the French organization, for example, reflects the weakness of the French parliament, suggested La Porte. Organizations in Denmark and the Netherlands work directly to engage the interest of the general public, reflecting the participatory nature of democracy in these countries. "If there is less of a role for fact-based decision-making in the US Congress," he said, "the Holland-Denmark model might be worth taking a look at".

Colin Macilwain

\section{Cancer link to power cables 'exaggerated', say critics}

London. The publishers of a peer-reviewed medical journal, and the Medical Research Council (MRC), have provoked controversy by helping to publicize a television programme that, some claim, exaggerates the results of a study of potential links between electromagnetic radiation and cancer.

Advance publicity for the programme, due to be broadcast on Wednesday night in Channel 4's series 'Dispatches', suggests that the researchers, whose work was carried out at the University of Bristol and supported by the MRC, have found such a link.

A notice issued to the press says that the team's results go "further than ever before" in showing how "electromagnetic fields surrounding both power lines and domestic mains leads to certain types of cancer". It

\section{IMAGE \\ UNAVAILABLE FOR COPYRIGHT REASONS}

Over the top? 'No persuasive evidence' of a link between electric fields and cancer.

adds: "evidence of how these fields could cause cancer has previously baffled scientists - until now". One subsequent headline in the Times read: "Scientists link power lines to cancer".

But the research, published on the same day in the International Journal of Radiation Biology, explicitly denies that it has shown any such link. In their paper, "Enhanced deposition of radon daughter nuclei in the vicinity of power frequency magnetic fields", Denis Henshaw and colleagues speculate about a possible link between certain types of cancers and the inhalation of radon decay products that are influenced by electric fields. But they state in their abstract that "at present, there still remains no persuasive biological evidence that power frequency electromagnetic fields can influence any of the accepted stages in carcinogenesis".

Paul Fawcett, a spokesman for the MRC, says that the press notice, circulated by Taylor \& Francis, publishers of the journal, was intended primarily as an invitation to an advance screening of the documentary. He adds that both Henshaw and MRC were slightly "annoyed" about the wording, but stand by its content as well as that of the television programme, and he denies that the MRC was "hyping the research".

Richard Horton, sales and marketing director for Taylor \& Francis, also defends the press notice, pointing out that it had been circulated with the knowledge and consent of all concerned. "Some requested changes. Some changes were made," he says. "As publishers of the article and not the scientific expertise behind it, my advice is to see the programme."

Researchers have for some time been investigating claims of a possible link between power lines and cancer. So far, however, the evidence remains patchy. Epidemiological studies show an association between exposure to electromagnetic fields and cancer. But studies at the cellular level have failed to establish that such fields are the cause of the observed disease.

James Metcalfe, of the department of biochemistry at the University of Cambridge, was a participant in a three-year research project that tried unsuccessfully to replicate a much-cited study that claimed exposure to electromagnetic fields increases the risk of leukaemia (see Nature 375, 22; 1995). Although Metcalfe says the Henshaw paper is not wrong to speculate about a potential link between radon decay products, electric fields and cancer, he points out that the paper emphasizes that a cause has yet to be established, and describes the publicity for the paper as "oversimplified".

But Michael O'Riordan, a spokesman for the National Radiological Protection Board, says the theory being put forward by Henshaw and colleagues - namely that electric fields can enhance the effects of inhaled radon - is "implausible". O'Riordan says that the effect of electric fields on radon decay products, which decay from uranium in the ground and rise into the atmosphere as part of soil gas, has been known since 1901. He also acknowledges that a link has been established between radon decay products, known as 'daughters', and lung cancer.

But O'Riordan says that Henshaw's proposal conflicts with established scientific literature. Electric fields, he says, cause radon decay products to stick to surfaces. "The consequence is that fewer radon daughters remain in the air to be breathed by occupants, so exposure is lowered."

At the beginning of this week, Henshaw and the Bristol team said that they had agreed with the MRC not to comment on reports about the programme's content until its advance screening on Tuesday (13 February), despite widespread reports in newspapers based on the earlier press notice.
Ehsan Masood 